Apidologie, 1980, 11 (1), 75-86.

\title{
AMINO ACIDS AND PROTEIN ADEQUACY FOR HONEY BEES OF POLLENS FROM DESERT PLANTS AND OTHER FLORAL SOURCES
}

\author{
W. F. McCAUGHEY \\ Department of Nutrition and Food Science \\ University of Arizona, Tucson, Arizona 85721 \\ and \\ Martha GILLIAM* and L. N. STANDIFER* \\ * Carl Hayden Bee Research Center \\ Agricultural Research, U.S.D.A., S.E.A., \\ 2000 E. Allen Road \\ Tucson, $A Z 85719$
}

\section{SUMMARY}

Honey bees, Apis mellifera, require protein from pollen primarily as a source of essential amino acids. Thus, we determined the amino acids and protein contents of hand-collected pollens from selected desert plants that bees sometimes visit and from other floral sources. Prickly pear pollen that is seldom collected by honey bees had the lowest protein content and creosote bush, a pollen source for bees, the highest. Glutamic acid, aspartic acid, and proline were the predominant amino acids in all desert pollens examined. The desert plants had low protein levels, but their amino acid patterns were in agreement with the requirements for honey bees with the exception that catclaw pollen, which is seldom collected by bees, was low in methionine. Since honey bees rarely feed on one floral source, the low protein levels of these pollens could be compensated by collection of pollens that have high protein levels. Also, since desert plants are valuable nectar sources for bees in Arizona, pollen collection may be incidental to nectar collection for honey production. These pollens might also be collected by bee colonies that are rearing brood and have a shortage of pollen.

Analyses of data from pollens from floral sources other than desert plants revealed a significant correlation between the level of protein ingested (but not the essential amino acid composition) and the development of the hypopharyngeal glands of worker bees. 


\section{INTRODUCTION}

Honeybees, Apis mellifera L., require protein from pollen primarily as a source of essential amino acids, and the total protein of flowering plant pollens varies from 7$35 \%$ (see BARBIER, 1970). In Arizona, honey bees often collect pollen and nectar from desert plants either because of the attractiveness of these plants to bees or because of the lack of competitive cultivated crop plants in some areas.

Little data exist on the amino acid compositions and protein levels of pollens from desert plants. BIEBERDORF et al. (1961) detected by paper chromatography 11 free amino acids in pollen from mesquite (Prosopis julifora (Swartz) DC.). However, these were not identified. BritiKov and Musatova (1964) reported that pollen of Opuntia Mill. sp. is approximately $0.5-0.6 \%$ free proline. Proline, glutamic acid, and aspartic acid are usually found in high levels in pollens (STANLEY and LiNSKENS, 1974).

The amino acids in pollens are required by the bee for synthesis of tissues, hemolymph proteins, enzymes, etc. These include the essential amino acids which the bee cannot synthesize and the non-essential amino acids which the bee can transform metabolically from one to another (as man and other animals do) or which it can synthesize from certain essential amino acids (e.g. tyrosine from phenylalanine, cysteine from methionine, etc.). The essential amino acids are an absolute dietary requirement for the bee, qualitatively and quantitatively, as established by DEGroot (1953). The quantitative relationship emerges as a " pattern ", that is, the ratios of essential amino acids, one to another, that have been fairly well-established over the years for man and many species of animals. This pattern has been shown to vary significantly with the species, sex, age, condition of health, and metabolic activity of the individual under consideration. Utilization of a particular amino acid at the cellular level can be influenced by relative concentrations of other specific amino acids in the diet (e.g. lysine vs. arginine, leucine vs. isoleucine). "Sparing effects" of one amino acid on another have been shown to occur (tyrosine spares the requirement for phenylalanine; cysteine spares methionine). Amino acid requirements can also be influenced by particular vitamins in the diet, by total caloric intake, or by dietary enzyme inhibitors or other factors not yet elucidated.

In judging dietary protein adequacy of pollens or pollen substitutes for bees, MAURIzIO (1954), StandifER et al. (1960), and others have used hypopharyngeal gland development of worker bees as a criterion, but there is a paucity of information in the literature correlating these observations with essential amino acid compositions of the various substances fed during these studies. It would be extremely informative if we could demonstrate that bees feeding on pollen from one plant species showed excellent brood rearing or hypopharyngeal gland development compared with bees consuming pollen from another species and doing poorly and could explain this observation by a well-balanced essential amino acid pattern found in the first pollen compared with deficiencies in particular amino acids in the second pollen. At this 
time, it cannot be assumed that a diet that allows maximum hypopharyngeal gland development will also be adequate for growth and development of larvae. Similarly, data on bee tissue may be misleading since they will vary according to the physiological state of the bees and the conditions within the hive.

Two of the many different methods for chemically evaluating protein adequacy are considered in the present paper : 1) the F.A.O. pattern developed by the U.N. Food and Agricultural Organization's Nutrition Research Council for human requirements (United Nations Joint F.A.O./W.H.O. Expert Committee on Protein Requirements, 1965), and 2) the chemical score technique developed by Mitchell and BLOCK (1946) and later modified by OSER (1951). Table 1 shows reference data based on the F.A.O.

TABL. 1. - Reference data for comparison of pollen effectiveness as a protein source for bees.

\begin{tabular}{l|c|c|c|c}
\hline \hline Amino acid (a) & $\begin{array}{c}\text { Bee } \\
\text { requirement (b) }\end{array}$ & $\begin{array}{c}\text { Bee } \\
\text { tissue } \\
\text { content (c) }\end{array}$ & $\begin{array}{c}\text { Egg } \\
\text { albumin (d) }\end{array}$ & $\begin{array}{c}\text { Whole } \\
\text { egg } \\
\text { powder (d) }\end{array}$ \\
\hline Threonine & 3.0 & 3.0 & 4.88 & 4.7 \\
Phenylalanine & 2.5 & 2.8 & 5.94 & 4.8 \\
Leucine & 4.5 & 6.6 & 8.77 & 9.0 \\
Isoleucine & 5.0 & 1.5 & 6.45 & 7.8 \\
Lysine & 3.0 & 5.0 & 7.20 & 6.2 \\
Arginine & 3.0 & 3.5 & 5.98 & 2.4 \\
Histidine & 1.5 & 2.3 & 2.42 & 6.8 \\
Valine & 4.0 & 2.3 & 7.46 & 3.3 \\
Methionine & 1.5 & 1.4 & 4.16 & \\
\hline
\end{tabular}

(a) Arranged in descending order of need for growth of young adult bees (DEGroot, 1953).

(b) Quantitative requirement (as a ratio with $\mathrm{Thr}=3.0$ ) (DEGroor, 1953).

(c) Composition of fresh bee tissue (as a ratio with $\mathrm{Thr}=3.0$ ) (MCCAughey and Longo, unpublished data).

(d) Grams/100 grams of protein.

pattern used in an attempt to evaluate the adequacy for bees of the various pollens for which the amino acid compositions are reported in this paper. Comparisons are made as explained later.

Since some desert plants are sources of pollens for honey bees, we report here the examination of pollens of selected species for total amino acids. As noted later, samples of these pollens were hand-collected and were not of sufficient quantities to permit brood-rearing or hypopharyngeal gland development studies with captive bees, which would have been desirable in order to evaluate more fully the protein adequacy of the desert plant pollens. Consequently, we report here amino acid data (not heretofore published) from various plant pollens, that were used by STANDIFER et al. (1960) and STANDifER (1967) in earlier studies, in an attempt to show significant correlation between hypopharyngeal gland development and essential amino acid 
composition. This study is part of a long-range project to obtain the necessary information for developing pollen substitutes.

\section{MATERIALS AND METHODS}

Pollens were hand-collected during the mornings of May 1976 from the following plants in the desert surrounding the Tucson area : prickly pear cactus (Opuntia sp.), burroweed (Haplopappus tenuisectus (Greene) Blake], catclaw (A cacia greggi Gray), Mexican palo verde (Parkinsonia aculeata L.) saguaro cactus |Cereus giganteus (Engelm.)|, cholla cacti (two undetermined Opuntia spp., one green and one purple), mesquite (Prosopis velutina Woot.), and creosote bush ILarrea tridentata (DC.) Covillel. The pollen samples were brushed with small clean paint brushes or cut from the flowers with surgical scissors and placed in sterile vials. All vials were immediately placed on dry ice for transfer to the laboratory and were kept at $-70^{\circ} \mathrm{C}$ in a freezer until analyzed.

The crude protein level of the air-dried pollen samples was determined by the microkjeldahl technique (KIRK, 1950). Moisture percentages were not determined. Fifty-100 mg of each pollen sample were hydrolyzed with $6 \mathrm{~N} \mathrm{HCl}$ and examined with a Beckman Model 121 amino acid analyzer (1) for total amino acids as previously described (Gilliam et al., 1980). Samples were analyzed in duplicate when possible, and values were reported on an air-dried basis.

\section{RESULTS AND DISCUSSION}

Table 2 shows the total amino acids and percent crude protein of the desert pollens. The percent crude protein ranged from a low of 7.0 in prickly pear to a high of 15.6 in creosote bush. All pollens contained detectable levels of the 17 amino acids measured. Glutamic acid, aspartic acid, and proline were the predominant amino acids and also showed the greatest variation between species. Lysine and leucine, two amino acids essential for honey bees (DEGROOT, 1953), were also found in high levels.

It is of interest that creosote bush pollen contained the highest level of glutamic acid $(17 \%)$ and the lowest level of aspartic acid $(7.7 \%)$ of the pollens. Also, only in palo verde pollen was proline the major amino acid, comprising $19.6 \%$ of the crude protein. Mesquite pollen contained a high level (3.4\%) of cysteine in comparison to the other pollens. This is discussed later in connection with the somewhat low methionine content of this pollen. Amino acids accounted for $63.7-99.5 \%$ of the crude protein in pollens after acid hydrolysis. Catclaw pollen had the lowest percent of amino acids and palo verde the highest.

Table 3 shows the essential amino acids in these same pollens calculated on the basis of threonine $=3.0$ (presenting a "pattern") (United Nations Joint F.A.O./W.H.O. Expert Committee on Protein Requirements, 1965) to permit scan ning for possible deficiencies by comparison with the quantities shown as the bee require-

(1) Mention of a proprietary product in this paper does not constitute an endorsement of this product by the USDA 


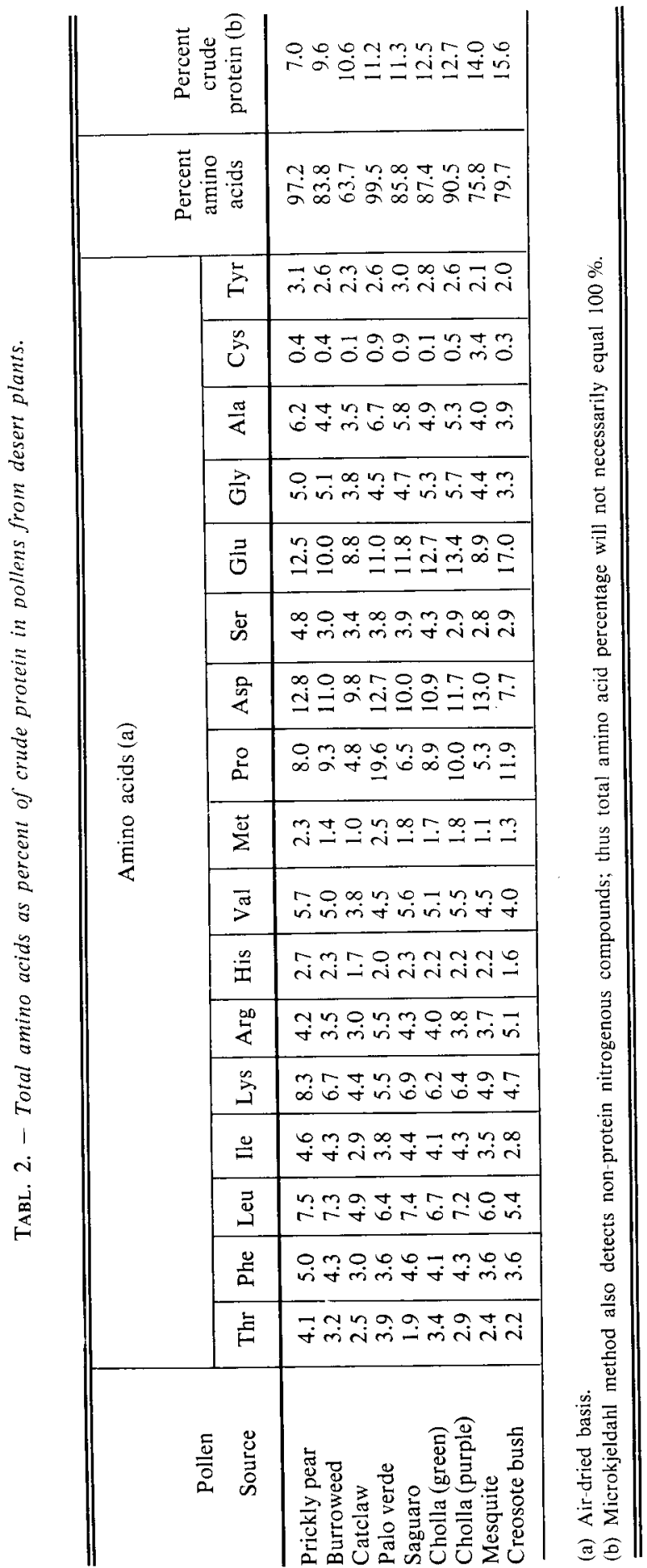


TABL. 3. - Essential amino in desert plant pollens as ratios with threonine $=3.0$ compared with bee requirements and bee tissue amino acials.

\begin{tabular}{l|r|r|r|r|r|r|r|r|l}
\hline \hline \multirow{2}{*}{$\begin{array}{l}\text { Pollen } \\
\text { Source }\end{array}$} & \multicolumn{7}{|c}{ Amino acids (a) } \\
\cline { 2 - 10 } & Thr & Phe & Leu & Ile & Lys & Arg & His & Val & Met \\
\hline Prickly pear & 3.0 & 3.7 & 5.5 & 3.4 & 6.1 & 3.1 & 2.0 & 4.2 & 1.7 \\
Burroweed & 3.0 & 4.0 & 6.8 & 4.0 & 6.3 & 3.3 & 2.2 & 4.7 & $\underline{1.3}$ \\
Catclaw & 3.0 & 3.6 & 5.9 & $\underline{3.5}$ & 5.3 & 3.6 & 2.0 & 4.6 & $\underline{1.2}$ \\
Palo verde & 3.0 & 2.8 & 4.9 & 2.9 & 4.2 & 4.2 & 1.5 & $\underline{3.5}$ & 1.9 \\
Saguaro & 3.0 & 7.3 & 11.7 & 6.9 & 10.9 & 6.8 & 3.6 & 8.8 & 2.8 \\
Cholla (green) & 3.0 & 3.6 & 5.9 & 3.6 & 5.5 & 3.5 & 1.9 & 4.5 & 1.5 \\
Cholla (purple) & 3.0 & 4.4 & 7.4 & 4.4 & 6.6 & 3.9 & 2.3 & 5.7 & 1.9 \\
Mesquite & 3.0 & 4.5 & 7.5 & 4.4 & 6.1 & 4.6 & 2.8 & 5.6 & $\underline{1.4}$ \\
Creosote bush & 3.0 & 4.9 & 7.4 & 3.8 & 6.4 & 7.0 & 2.2 & 5.5 & 1.8 \\
\hline Bee requirement (b) & 3.0 & 2.5 & 4.5 & 5.0 & 3.0 & 3.0 & 1.5 & 4.0 & 1.5 \\
Tissue content (c) & 3.0 & 2.8 & 6.6 & 1.5 & 5.0 & 3.5 & 2.3 & 2.3 & 1.4 \\
\hline
\end{tabular}

(a) Underlined values are possibly deficient in terms of requirement.

(b) DEGROOT (1953).

(c) Fresh tissue basis (MCCAughey and Longo, unpublished data).

ment according to DeGroot (1953). Generally, the essential amino acid pattern appears to be adequate in all the pollens, with the possible exception of somewhat low levels of methionine in burroweed, catclaw, and mesquite; valine in palo verde; and isoleucine in prickly pear, catclaw, and palo verde pollens. Again, comparison with the amino acids found in bee tissue (with threonine $=3.0$ ) would imply adequate quantities in all the pollens, but the low crude protein levels counteract this. However, since bees rarely feed on pollen from one floral source, the low protein levels of desert pollens could be compensated by high protein levels of pollens from other sources.

The chemical score of Mitchell and Block (1946) provides a means of estimating the nutritional efficiency of a protein source by comparing its essential amino acid content with that of whole egg protein (e.g. threonine in the protein $\div$ threonine in egg $\times 100=\%$ of threonine requirement present in the protein for the animal). The lowest percentage obtained represents the limiting essential amino acid in that protein, is known as the chemical score. and is indicative of the relative nutritional efficiency for the species of animal being tested, of that protein source compared with egg protein, which is considered to be the perfect protein. Of course, we recognize that egg protein is not the perfect protein for bees. Although an appropriate nomogram has not been published for the honey bee by this technique, STANDIFER et al. (1960) found egg albumin to be the most effective pollen substitute tested (see Tabl. 5) in terms of maximum hypopharyngeal gland development. Use of the chemical score method for bees, then, would not seem too unrealistic.

Diverging a bit from the desert plant pollens, we present in Table 4 the amino acid compositions of egg albumin and plant pollens from various sources which were 


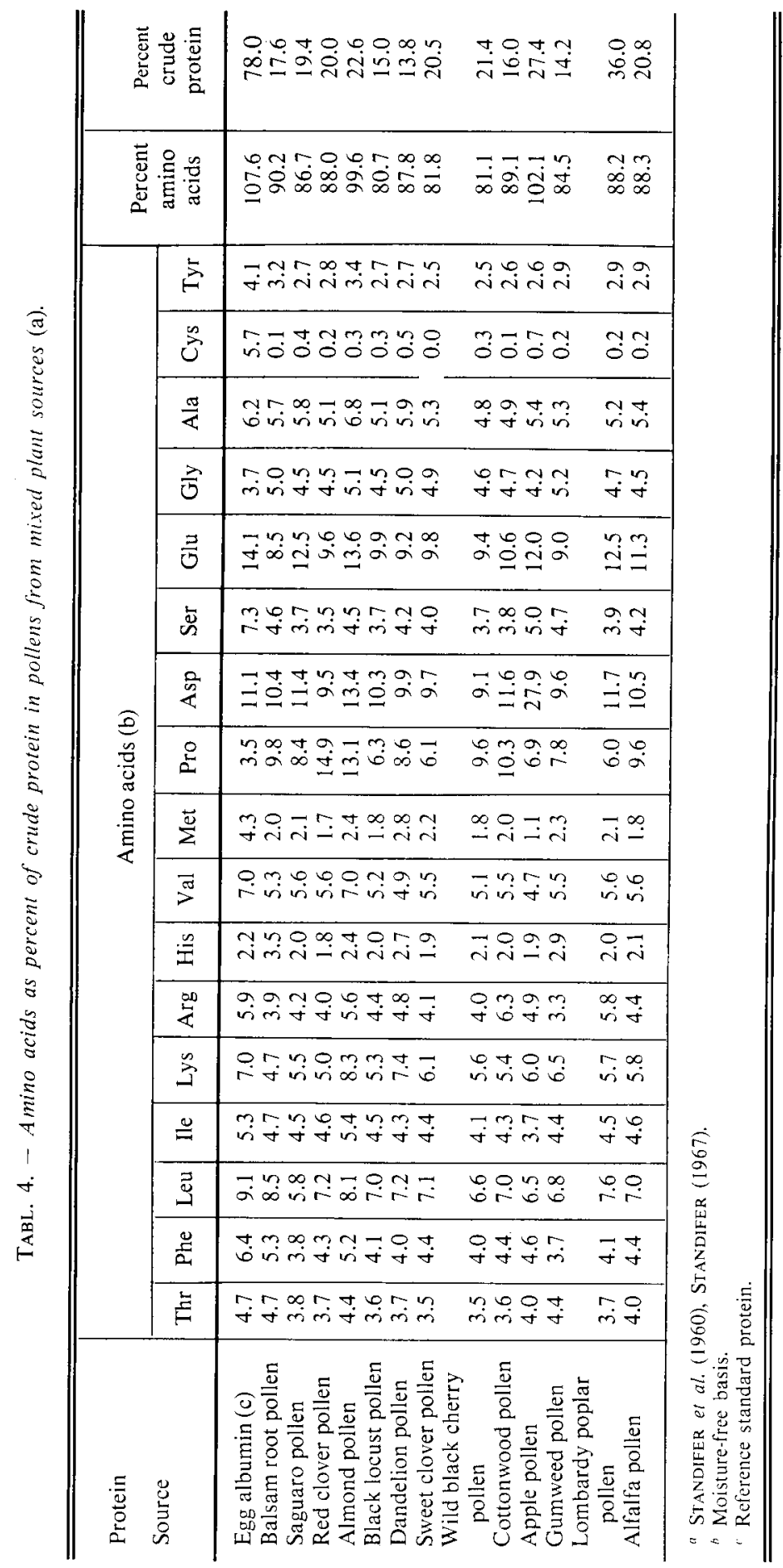


TABL. 5. - Correlation of hypopharyngeal gland development with various amino acid factors.

\begin{tabular}{|c|c|c|c|c|c|c|}
\hline \multirow{2}{*}{$\begin{array}{l}\text { Protein } \\
\text { Source (a) }\end{array}$} & \multirow{2}{*}{$\begin{array}{l}\text { Gland } \\
\text { development } \\
\text { (b) }\end{array}$} & \multirow{2}{*}{$\begin{array}{c}\text { Chemical } \\
\text { score (c) } \\
(\%)\end{array}$} & \multicolumn{2}{|c|}{ Total amino acids } & \multirow{2}{*}{$\begin{array}{l}\text { Leu/Ile } \\
\text { (ratio) }\end{array}$} & \multirow{2}{*}{$\begin{array}{l}\text { Lys/Arg } \\
\text { (ratio) }\end{array}$} \\
\hline & & & $\begin{array}{c}\text { essential } \\
(\%)\end{array}$ & $\begin{array}{c}\text { non- } \\
\text { essential } \\
(\%)\end{array}$ & & \\
\hline Egg albumin & 3.7 & 91.4 & 48.2 & 51.8 & 1.72 & 1.19 \\
\hline Balsam root pollen & 3.6 & 60.6 & 47.4 & 52.6 & 1.80 & 1.20 \\
\hline Saguaro pollen & 3.5 & 62.4 & 43.0 & 57.0 & 1.29 & 1.30 \\
\hline Red clover pollen & 3.4 & 51.5 & 43.1 & 56.9 & 1.56 & 1.23 \\
\hline Almond pollen & 3.3 & 73.6 & 44.8 & 55.2 & 1.48 & 1.49 \\
\hline Black locust pollen & 3.3 & 55.8 & 47.1 & 52.9 & 1.57 & 1.21 \\
\hline Dandelion pollen & 3.1 & 40.3 & 47.6 & 52.4 & 1.67 & 1.54 \\
\hline Sweet clover pollen & 3.0 & 66.1 & 48.1 & 51.9 & 1.60 & 1.48 \\
\hline Wild black cherry pollen & 2.9 & 56.1 & 45.9 & 54.1 & 1.60 & 1.42 \\
\hline Cottonwood pollen & 2.8 & 52.9 & 45.7 & 54.3 & 1.63 & 0.86 \\
\hline Apple pollen & 2.8 & 33.0 & 36.6 & 63.4 & 1.76 & 1.22 \\
\hline Gumweed pollen & 2.6 & 53.7 & 47.2 & 52.8 & 1.57 & 1.95 \\
\hline Lombardy poplar pollen & 2.0 & 62.4 & 46.7 & 53.3 & 1.68 & 1.00 \\
\hline Alfalfa pollen & 2.0 & 55.2 & 45.1 & 54.9 & 1.54 & 1.32 \\
\hline
\end{tabular}

(a) STANDifer et al. (1960), StANDiFER (1967).

(b) 4.0 good; 1.0 poor.

(c) MitChell and Block (1946).

earlier used by STANDIFER et al. (1960) and STANDIFER (1967) to feed captive bees and observe development of the hypopharyngeal glands. If these data are reduced to ratios with threonine $=3.0$ (not shown here), all of the pollens appear to be fairly adequate in essential amino acid content. In Table 5, the protein sources are listed in decreasing order of hypopharyngeal gland development $(4.0=$ complete development $)$, along with the comparable values for chemical score, and other parameters, which were calculated from the data in Table 4. Although egg albumin and the first four pollens showing good hypopharyngeal gland development (3.3-3.7) also correlate well with fairly good chemical scores (51.5-91.4), this relationship does not hold for the remain ing pollens. Regression analysis (Little and Hill, 1972) of the entire 14 protein sour ces yields a correlation coefficient of 0.34 , which is not statistically significant. In fact, only for dandelion and apple pollens (scores of $40.3 \%$ and $33.0 \%$ respectively) could we safely predict poor performance in bees feeding on these sources.

Although good rationale exists for the next three parameters (\% essential and nonessential amino acids, leucine/isoleucine ratio, and lysine/arginine ratio) in studies of protein adequacy for mammals, no significant correlations can be found with the observed differences in hypopharyngeal gland development (Tabl. 5). Thus, some factor or combination of factors other than the moderate variations in essential amino acid content must be responsible for the differences found in hypopharyngeal gland 
development. Lack or deficiencies of vitamins may be important. Two alternative explanations are also possible: 1) subtle differences in the ratios of certain amino acids - essential or non-essential - may be significant but have been missed by us in studying the data, or 2) the essential amino acid tryptophan may be deficient in the case of the poorer pollens. Tryptophan is destroyed during protein hydrolysis by acid and can be isolated only by treating additional pollen samples to a laborious alkaline or enzymatic hydrolysis. In most of the studies reported here, the amounts of pollen available were too limited to allow determination of tryptophan. In other studies in which sufficient pollen was at hand to permit tryptophan analysis, this amino acid was never found to be the limiting essential amino acid.

Despite the lack of significance of the essential amino acid data discussed above, it was of interest to reaffirm the importance of protein in the diet of the bee. Table 6

TABL. 6. - Hypopharyngeal gland development in the honeyee as infuenced by amount of ingested protein (a).

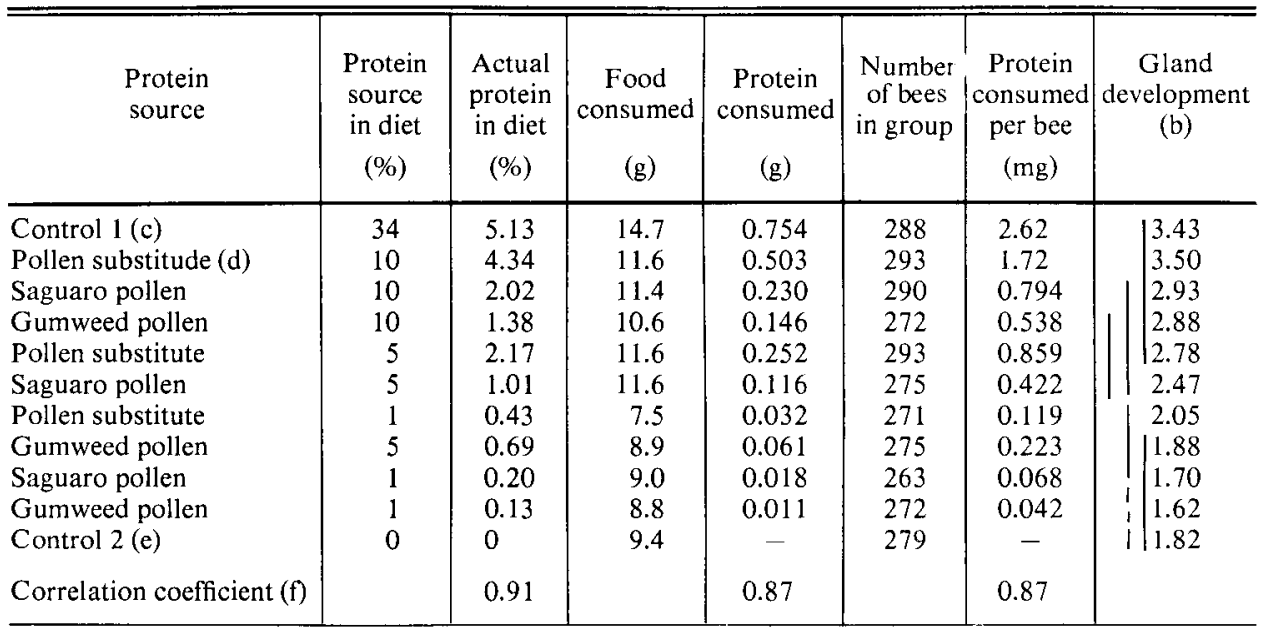

(a) STANDIFER et al. (1970).

(b) Scale of 4.0 (good) to 1.0 (poor); any two means not connected by the same line are significantly different ( $\mathrm{p}^{--} 0.05$ ).

(c) Dandelion pollen.

(d) Soy flour 3, skim milk 1, brewers yeast $1+$ carbohydrate.

(e) Carbohydrate only, no protein.

(f) From regression analysis $(+1.0=$ perfect correlation).

presents an expanded consideration of data reported by STANDIFER et 'al. (1970) in which hypopharyngeal gland development is related to the amount of ingested protein. Regression analysis (LITTLE and HiLL, 1972) yielded highly significant $(p=.01)$ correlation coefficients for the level of protein in the diet $(0.91)$, for total protein consumed by each of the bee groups studied $(0.87)$, and for protein consumed by the individual bee (0.87). As reported by STANDIFER et al. (1970), significant 
differences in hypopharyngeal gland development were statistically determined by the Duncan multiple-range test (1955). The observed differences certainly emphasize the importance to bee performance of the quantity, if not the quality, of the protein source.

The amino acid data for the desert plant pollens (Tabl. 2) were used to calculate the chemical score, leucine/isoleucine and lysine/arginine ratios, and the percentages of essential and non-essential amino acids for each pollen (see Tabl. 7) Also included are the observations on whether bees frequently or seldom collect the particular pollen listed. No significant correlations are obvious in the listed data; however, two possibilities should be mentioned. The low chemical score for catclaw pollen $(30.3 \%)$ is due to low methionine content (see Tabl. 3 : a ratio of $1.2 \mathrm{vs}$. the bee requirement of 1.5), which may be related to bees not often collecting this pollen. Also, although mesquite pollen also has a low chemical score $(33.3 \%)$ due to deficient methionine, it has a higher ratio (Tabl. 3) of 1.4 vs. the 1.5 required; but more importantly the significantly larger cysteine content $(3.4 \%$ vs. the usual average of about $0.5 \%-$ Tabl. 2) undoubtedly has a sparing effect on the methionine requirement for the bee, an effect similar to that shown for mammals. This fact may contribute to the greater attractiveness of mesquite than catclaw pollen, although other factors such as phagostimulants may play a greater role.

Honey bees do not often collect pollen from all the desert species that we examined (Tabl. 7). Research has been reported only on saguaro that was found to

TABL. 7. - Various amino acid parameters for desert plant pollens.

\begin{tabular}{|c|c|c|c|c|c|c|c|}
\hline \multirow{2}{*}{$\begin{array}{l}\text { Pollen } \\
\text { source }\end{array}$} & \multicolumn{2}{|c|}{$\begin{array}{l}\text { Collected } \\
\text { by bees : }\end{array}$} & \multirow{2}{*}{$\begin{array}{c}\text { Chemical } \\
\text { score (a) } \\
(\%)\end{array}$} & \multicolumn{2}{|c|}{ Total amino acids } & \multirow[b]{2}{*}{$\begin{array}{l}\text { Leu/Ile } \\
\text { (ratio) }\end{array}$} & \multirow[b]{2}{*}{$\begin{array}{r}\text { Lys/Arg } \\
\text { (ratio) }\end{array}$} \\
\hline & Often & Seldom & & $\begin{array}{c}\text { essential } \\
(\%)\end{array}$ & $\begin{array}{c}\text { non- } \\
\text { essential } \\
(\%)\end{array}$ & & \\
\hline $\begin{array}{l}\text { Prickly pear } \\
\text { Burroweed } \\
\text { Catclaw } \\
\text { Palo verde } \\
\text { Saguaro } \\
\text { Cholla (green) } \\
\text { Cholla (purple) } \\
\text { Mesquite } \\
\text { Creosote bush }\end{array}$ & $\begin{array}{l}* \\
* \\
*\end{array}$ & * & $\begin{array}{l}67.7 \\
42.4 \\
30.3 \\
65.5 \\
40.4 \\
51.5 \\
54.5 \\
33.3 \\
39.4\end{array}$ & $\begin{array}{l}45.7 \\
45.3 \\
42.7 \\
37.9 \\
45.7 \\
42.9 \\
42.4 \\
42.1 \\
38.5\end{array}$ & $\begin{array}{l}54.3 \\
54.7 \\
57.3 \\
62.1 \\
54.3 \\
57.1 \\
57.6 \\
57.9 \\
61.5\end{array}$ & $\begin{array}{l}1.6 \\
1.7 \\
1.7 \\
1.7 \\
1.7 \\
1.6 \\
1.7 \\
1.7 \\
1.9\end{array}$ & $\begin{array}{l}2.0 \\
1.9 \\
1.5 \\
1.0 \\
1.6 \\
1.6 \\
1.7 \\
1.3 \\
0.9\end{array}$ \\
\hline
\end{tabular}

(a) Mitchell and Block (1946).

benefit from bee pollination and to produce about 25 bee-loads of pollen per flower, an amount unsurpassed by any other flower (MCGREGCR et al., 1962). Burroweed, palo verde, mesquite, and creosote bush are also pollen sources for bees. All of these in addition to saguaro and catclaw are also honey plants. However, honey bees seldom 
collect pollen from prickly pear, catclaw, or cholla, although we observed many pollencollecting honey bees from a nearby apiary on the purple cholla. They also rarely collect nectar from prickly pear or cholla. Collection of pollen from desert flowers may result either because of the value of these plants as nectar sources in which case pollen collection is incidental to nectar collection or because a shortage of pollen exists in colonies that are rearing brood. TODD and BRETHERICK (1942) stated that the nutritive value of pollen for bees is not directly correlated with protein quantity since a qualitative factor is of greater importance.

Received for publication n November 1979.

\author{
RÉSUMÉ \\ ACIDES AMINÉS ET PROTÉINES DE POLLENS PROVENANT DE PLANTES DÉSERTIQUES \\ ET D'AUTRES SOURCES FLORALES ET LEUR CARACTÈRE APPROPRIÉ \\ POUR LES ABEILLES
}

On a déterminé la teneur totale en acides aminés et la teneur brute en protéines de pollens récoltés à la main sur des plantes désertiques sélectionnées. Le pollen de figuier de Barbarie, rarement butiné par les abeilles, a la plus forte teneur en protéines et celui de " creosote bush " (Larrea tridentata), source de pol len pour les abeilles, la plus forte. L'acide glutamique, l'acide aspartique et la proline sont les principaux acides aminés dans tous les pollens de désert examinés. Ces pollens possèdent un éventail d'acides aminés essentiels qui correspond réellement aux besoins de l'abeille tels qu'ils ont été déterminés par DEGROOT ( 1953), à l'exception du pollen de "catclaw " (Acacia), rarement butiné par les abeilles et qui est pauvre en méthionine. Néanmoins les pourcentages bruts de protéines sont bas, allant de 7,0 pour le pollen de figuier de Barbarie à 15,6\% pour celui de " creosote bush».

L'examen des pollens provenant de diverses plantes utilisées auparavant par STANDIFER (1967) et STANDIFER et al. (1960) pour déterminer le développement des glandes hypopharyngiennes des ouvrières a montré une absence de corrélation significative entre la composition en acides aminés essentiels et la réaction physiologique. Pourtant le traitement statistique des données d'une autre étude (STANDIFER et al., 1970) a montré une corrélation hautement significative entre le développement des glandes hypopharyngiennes et la quantité de protéines ingérée. Un certain facteur ou une combinaison de facteurs, autres que des variations faibles de la teneur en acides aminés essentiels, doit donc être responsable des différences dans le développement des glandes hypopharyngiennes. Les différences observées soulignent l'importance pour le fonctionnement de l'abeille de la quantité, et non de la qualité, de la source protéinique.

\title{
ZUSAMMENFASSUNG
}

DIE AMINOSÄUREN DES POLLENS VON WÜSTENPFLANZEN UND ANDERER PFLANZLICHER QUELLEN UND DIE BIOLOGISCHE WIRKSAMKEIT VON DEREN PROTEINEN AUF DIE HONIGBIENEN

Von ausgewählten Arten von Wüstenpflanzen wurden die gesamten Aminosäuren und der rohe Gehalt an Proteinen bestimmt. Der Pollen von Feigenkaktus, der von Honigbienen nur selten gesammelt wird, hatte den niedrigsten Proteingehalt, und der vom Kreosotstrauch, einer Pollenquelle für Bienen, den höchsten. Glutaminsäure, Aspariginsäure und Prolin waren die vorherrschenden Aminosäuren in allen untersuchten Wüstenpollen. Diese Pollen zeigten ein Muster an essentiellen Aminosäuren, das grundsätzlich mit den Bedürfnissen der Bienen übereinstimmt, wie es von DEGroot (195.3) bestimmt worden war - ausgenommen Catclaw- (Acacia-) Pollen, der nur selten von Bienen gesammelt wird und 
der sich als niedrig im Methioningehalt erwies. Der prozentuelle Gehalt an Gesamtproteinen war jedoch niedrig, zwischen 7,0 bei Pollen von Feigenkaktus bis 15,6 bei Pollen vom Kreosotstrauch.

Die Untersuchung von Pollen von verschiedenen Pflanzen, die in früheren Arbeiten von STANDIFER (1967) und STANDIFER et al. (1960) zur Bestimmung der Hypopharyngealdrüsenentwicklung bei Arbeitsbienen benutzt worden waren, ergab das Fehlen einer signifikanten Korrelation zwischen der Zusammensetzung an essentiellen Aminosäuren und der physiologischen Wirkung. Die statistische Bearbeitung von Daten einer anderen Untersuchung (STANDIFER et al., 1970) ergab jedoch eine hochsignifikante Korrelation zwischen der Entwicklung der Hypopharyngealdrüsen und der Menge an aufgenommenen Proteinen. Es muss also irgendein Faktor oder eine Kombination von Faktoren und nicht die geringfügigen Schwankungen im Gehalt an essentiellen Aminosäuren für die Unterschiede in der Entwicklung der Hypopharyngealdrüsen verantwortlich sein. Die beobachteten Unterschiede betonen die Bedeutung der Quantität, wenn nicht der Qualität, der Proteinquelle für die Leistung der Bienen.

\section{REFERENCES}

Barbier M., 1970. - Chemistry and biochemistry of pollens. Prog. Phytochem., 2, 1-34.

Bieberdorf F. W., Gross A. L., Weichlein R., 1961. - Free amino acid content of pollen. Ann. Allerg., 19, 867-876.

Britikov E. A., Musatova N. A., 1964. - |Accumulation of free proline in pollen.| Fiziol. Rast., 11, 464-472.

DeGroot A. P., 1953. - Protein and amino acid requirements of the honeybee (Apis mellifica L.). Physiol. Coinp. Ecol., 3, 197-285.

Duncan D. B., 1955. - Multiple range and multiple F tests. Biometrics, 11, 1-42.

Gilliam M., MCCAughey W.F., Wintermute B., 1980. - Amino acids in pollens and nectars of citrus cultivars and in bee breads and honeys from colonies of honeybees, Apis mellifera, placed in citrus groves. J. Apic. Res. in press.

KIRK P. L., 1950. - Kjeldahl method for total nitrogen. Anal. Chem., 22, 354-358.

LITTLE T. M., HiLl F. J., 1972. - Statistical methods in agricultural research. Davis, California : University of California.

MaUrizio A., 1954. - Pollenernährung und Lebensvororgänge bei der Honigbiene (Apis mellifica L.). Landwirt. Jb. Schweiz, 68, 115-182.

MCGregor S. E., Alcorn S. M., Olin G., 1962. - Pollination and pollinating agents of the saguaro. Ecology, 43, 259-267.

Mitchell H. H., Block R. J., 1946. - Some relationships between the amino acid contents of proteins and their nutritive values for the rat. J. Biol. Chem., 163, 599-613.

OSER B. L., 1951. - Method for integrating essential amino acid content in the nutritional evaluation of protein. J. Am. Dietetic Assoc., 27, 396-402.

Standifer L. N., McCaughey W. F., Todd F. E., Kemmerer A. R., 1960, - Relative availability of various proteins to the honey bee. Ann. Entom. Soc. Amer., 53, 618-625.

STANDIFER L. N., 1967. - A comparison of the protcin quality of pollens for growth-stimulation of the hypopharyngeal glands and longevity of honey bees, Apis mellifera L. (Hymenoptera: Apidae). Insectes Sociaux, 14, 415-425.

Standifer L. N., MaCDonald R. H., Levin M. D., 1970. - Influence of the quality of protein in pollens and of a pollen substitute on the development of the hypopharyngeal glands of honcy bees. Ann. Entom. Soc. Amer., 63, 909-910.

Stanley R. G., Linskens H. F., 1974. - Pollen : biolog!, chemistry, management. New York : SpringerVerlag.

TODD F. E., Bretherick O., 1942. - The composition of pollens. I. Econ. Lim., 35, 312-317.

United Nations Joint F.A.I./W.H.O. Expert Committee on Protein Requirements, 1965. "Protein Requirements", F.A.O. Nutr. Meet. Rep. Ser. No. 37; W.H.O. Tech. Re'p. S'r. No. 301. Rome. 